\title{
Situs Megalitik Tutari sebagai Sumber Inspirasi Penciptaan Koreografi Site-Specific "Tutari MegArt Lithic"
}

\author{
IBG. Surya Peradantha ${ }^{1}$, Sri Rustiyanti, Wanda Listiani, \\ Fani Dila Sari
}

Prodi Seni Tari, Jurusan Seni Pertunjukan, Institut Seni Budaya Indonesia Tanah Papua

\begin{abstract}
Tutari Megalithic Site as the Source of Inspiration for Choreography Creation of Site-Specific "Tutari MegArt Lithic". The Tutari Megalithic Site is a large stone age civilization site located in Doyo Lama Village, Waibu District, Jayapura Regency, Papua. Visually, on this site, there are stones with various motifs of prehistoric paintings on them. However, if it is studied indepth, primarily through the perspective of choreography, this site has a broad potential to be a source of inspiration for creating works of art. Collaborating with previous research from the Papua Archeology Center, the creation of this Tutari MegArt Lithic artwork is focused on specific parts of the Tutari Megalithic site that can be used as inspiration for creating artworks. The method used in this writing is descriptive analysis. The purpose of this paper is to provide an overview of how choreography can collaborate across disciplines in the creation of works of art staged at the Tutari archaeological site. This paper describes the sources of inspiration for creating site-specific choreographic works of art entitled Tutari MegArt Lithic, including visual inspiration, artistic inspiration and idea inspiration.
\end{abstract}

Keywords: Tutari Megalithic Site; site-specific choreography; source of inspiration; painting motive

\section{Pendahuluan}

Situs Megalitik Tutari terletak di Kampung Doyo Lama, Distrik Waibu, Kabupaten Jayapura. Jika ditinjau dari koordinat, Situs Tutari berada pada $140^{\circ} 24^{\prime} 45^{\prime \prime}-140^{\circ} 27^{\prime} 17^{\prime \prime}$ Bujur Timur dan 02 $32^{\prime} 04^{\prime \prime}-02^{\circ} 34^{\prime} 08^{\prime \prime}$ Lintang Selatan (lihat pada Gambar 1). Dari pusat Kota Jayapura, situs ini berada sekitar $30 \mathrm{Km}$ arah Barat dan sekitar terletak sekitar $7 \mathrm{Km}$ arah Barat Bandar Udara Sentani. Situs ini memiliki luas kurang lebih $60.000 \mathrm{~m} 2$ serta berada di ketinggian antara 30-300 meter di atas permukaan laut (Sumber: Tim Penyusun Buku Mulok Kebudayaan Papua: Situs Megalitik Tutari, 2018: 4).
Situs Megalitik Tutari merupakan salah satu kawasan arkeologi yang memiliki tinggalan purbakala berupa lukisan di atas batu

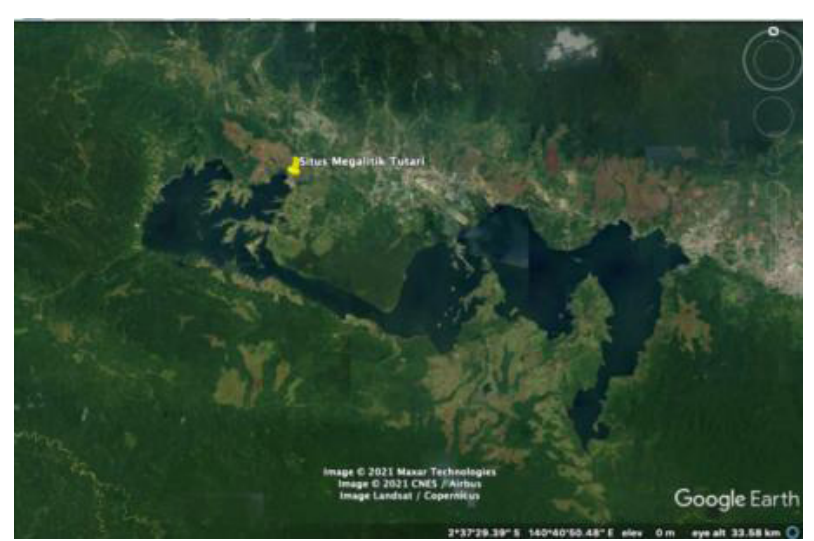

Gambar 1. Pin kuning menandakan lokasi Situs Megalitik Tutari dari Peta Google Earth. Sumber: Google Earth, IBG. Surya Peradantha, 2021.

1 Alamat korespondensi: Prodi Seni Tari, Jurusan Seni Pertunjukan, Institut Seni Budaya Indonesia Tanah Papua. Jl. Raya Sentani Km 17,8 Kel. Waena, Distrik Heram, Kota Jayapura. Email: gusde029@gmail.com. 
dengan berbagai motif, serta figur-figur dari batu yang memiliki makna khusus. Situs ini terbagi atas 6 sektor, dimana sektor 1-3 terdapat tinggalan berupa batu-batu berlukis; sektor 4 terdapat penginggalan batu berbentuk figur tertentu; sektor 5 memiliki tinggalan berupa susunan batu berbaris membentuk sebuah jalan dan sektor 6 terdapat tinggalan menhir atau batu yang diletakkan secara tegak yang berfungsi sebagai media pemujaan roh leluhur atau aktivitas spiritual tertentu anggota suku pada masa itu. Terdapat 110 buah menhir di sektor 6 yang ada di puncak Bukit Tutari ini.

Penelitian mengenai Situs Megalitik Tutari sesungguhnya telah dilakukan sejak lama. Pada tahun 1979, telah dilakukan studi awal dan survey lokasi purbakala di Situs Megalitik Tutari oleh Pusat Penelitian Arkeologi Nasional. Penelitian kemudian dilanjutkan pada tahun 1994-1995 juga oleh Pusat Penelitian Arkeologi Nasional dengan fokus penelitian pada pola tata ruang dan fungsi Situs Megalitik Tutari.

Pada tahun 2018 diterbitkanlah buku Mulok Kebudayaan Papua: Situs Megalitik Tutari oleh Balai Arkeologi Papua yang berisi tentang kumpulan hasil riset mengenai Situs Megalitik Tutari. Hasil-hasil penelitian inilah yang kemudian diseminarkan dan disosialisasikan kepada berbagai pihak seperti sekolah, dinas dan kampus, termasuk ISBI Tanah Papua. Pada tahun 2019, peneliti sekaligus koreografer, berkesempatan mengikuti acara Rumah Peradaban yang digelar oleh Balai Arkeologi Papua dengan materi utama yaitu mengenal lebih jauh Situs Megalitik Tutari. Dalam perjalanan mengunjungi situs tersebut, penulis merasa tertarik untuk mengamati tinggalan prasejarah yang ada di situs tersebut dan menjadikannya bahan kekaryaan koreografi site specific.

Di Papua khususnya, tari-tarian tradisional masyarakat biasanya dilakukan di area terbuka di alam. Ada yang menari di atas tanah lapang, di perbukitan, di atas perahu di danau dan dimanapun di alam terbuka yang memungkinkan. Sementara itu, penciptaan karya tari kreasi baru di Papua cenderung berfokus pada penciptaan tari-tari di atas panggung yang kaku baik berbentuk proscenium maupun panggung bentuk lainnya. Hal ini seolah melupakan karakteristik khas tarian tradisional Papua yang dekat dengan alam, karena sesungguhnya "panggung" pertunjukan tari masyarakat Papua adalah alam itu sendiri. Oleh karena itu, masyarakat suku pedalaman memiliki nilai kesetiaan yang tinggi dan patuh terhadap motto dan sumpah sakti yang dibuat dan disepakati oleh masyarakat pedalaman sejak dahulu kala (Suvina, Martion, dan Ali Sukri, 2020: 97).

Penciptaan koreografi site specific di Situs Megalitik Tutari merupakan suatu tantangan tersendiri bagi penulis. Selain menghadirkan karya koreografi dengan pendekatan garap site specific yang dipentaskan langsung di tempat dilakukan riset, kolaborasi disiplin ilmu antara arkeologi dan koreografi menjadikan riset yang dilakukan terasa lebih mendalam. Penulis merasa terbantu dengan adanya riset dari Balai Arkeologi Papua yang menghasilkan data referensi tertulis sehingga interpretasi yang dilakukan terhadap motifmotif lukisan di atas batu dan tinggalan lain di situs ini memiliki dasar yang dapat dipertanggungjawabkan. Selain itu, sebagai seorang dosen, penulis ingin memberikan pengalaman langsung kepada para mahasiswa untuk berkreativitas di luar kampus dengan memanfaatkan alam lingkungan sebagai tempat berekspresi. Pengalaman empiris melakukan riset, berproses dan berkarya langsung di tempat penelitian merupakan tantangan baru bagi para mahasiswa sejauh ini yang sangat berguna bagi kepekaan tubuh, pengembangan wawasan, penggalian ide dan kedalaman karya mereka di kemudian hari. Tentunya proses kreatif ini juga didasari atas keinginan untuk memperkenalkan Situs Megalitik Tutari melalui pendekatan seni pertunjukan kepada berbagai pihak sehingga upaya promosi dan preservasi situs ini menjadi lebih efektif. 
Karya ini diciptakan dengan terlebih dahulu meninjau literatur. Setiap koreografi selalu mengandung dua aspek yang tak terpisahkan antara isi dan bentuk. Di satu pihak menyikapi koreografi sebagai 'craft' yang menekankan prinsip-prinsip objektif dan aturan komposisi. Di lain pihak sebagai 'proses' yang menekankan cara kerjanya yang kreatif (Rustiyanti, 2019: 161). Mengingat pendekatan konsep garap yang digunakan dalam kaya ini adalah koreografi site specific dimana karakteristiknya berbeda dengan pementasan koegrafi panggung di ruang konvensional. Secara visual tempat pementasan, koreografi site specific dilakukan di ruang alternatif di luar panggung biasa (proscenium) atau black box. Ruang alternatif yang dimaksud dapat berupa stasiun kereta api, lorong pabrik, halte bus, dan ruang-ruang umum/publik lainnya.

Proses penciptaan untuk memantapkan pemahaman mengenai konsep koreografi site specific, artikel berjudul "Ruang Dan Memori Dalam Koreografi Site-Specific: Kajian Terhadap Karya City of Entertainment oleh Lee Ren Xin. Menurut J. Gonzales (2019) (dalam Nurulakmal, Becker dan Mustafa, 2020: 54), koreografi site specific adalah suatu karya yang terbentuk dan dilaksanakan di tempat khusus melalui inspirasi di tempat tersebut. Jelas dalam pengertian tersebut karya koreografi site specific terbentuk di tempat yang dianggap mampu memberikan daya imaginasi untuk kemudian dilakukan proses pewujudannya di tempat tersebut (onsite). Hal ini sangat penting untuk dipahami, karena selain merupakan karakteristik spesifik yang membedakannya dengan koreografi konvensional di atas panggung teater dan black box, karya semacam ini proses penggarapannya tidak bisa dilakukan di tempat selain tempat yang dimaksud serta tidak dapat dipresentasikan di lingkungan tempat selain tempatnya diwujudkan. Proses kreatif untuk melihat bagaimana seorang koreografer mengejawantahkan konsep karyanya ke dalam karya koreografi site specific, maka artikel berjudul "Embodying the Site: the Here and
Now in Site-Specific Dance Performance" dari Victoria Hunter (2005) turut dijadikan kajian. Poin penting yang didapat dari artikel ini adalah bagaimana seorang koreografer dapat hadir dan mengenali situs yang akan dijadikan tempat pertunjukan sekaligus berproses di dalamnya. Praktik dasar imajinasi terletak pada wujud kreatif "andai", yaitu tindakan yang dilakukan melalui penciptaan yang tiada menjadi ada (bisa berasal dari pengalaman pribadi yang disimpan dalam ingatan, pengalaman orang lain, atau dapat juga dari kemampuan mengkhayal) yang didukung oleh kemauan untuk melakukannya (Dewojati, 2012: 25). Dari kutipan tersebut menjelaskan bahwa ketika aktor tidak mengalami secara langsung peristiwa pada masa itu, maka hal yang perlu dilakukan adalah mengembangkan imajinasi, observasi, dan memperbanyak referensi (Situs Megalitik Tutari) untuk terciptanya sumber inspirasi yang diinginkan (Shinta Kusuma, Hirwan Kuardhani, dan Rukman Rosadi, 2020: 83).

Buku Mulok Kebudayaan Papua Untuk Sekolah Menengah Pertama yang diterbitkan oleh Balai Arkeologi Papua (2018), serta artikel berjudul "Makna Motif Lukisan Megalitik Tutari" (2017) oleh Erlin Novita Idje Djami dan Hari Suroto, memberikan data mengenai ragam jenis motif di Situs Megalitik Tutari beserta makna yang terkandung di dalamnya. Kedua tulisan ini merupakan hasil penelitian mengenai Situs Megalitik Tutari oleh Balai Arkeologi Papua dan merupakan beberapa di antara dokumen tertulis yang secara spesifik membahas Situs Megalitik Tutari sehingga buku ini dijadikan rujukan.

Karya Tutari MegArt Lithic ini diciptakan menggunakan metode penciptaan karya berbasis riset. Karya seni tidak lahir begitu saja, tetapi muncul dari sebuah ide gagasan yang kemudian disusun secara konseptual. Karya seni diekspresikan dari kontekstual dan tekstual yang komplek dari pembuatan sebuah karya seni dari pemikiran dan pengalaman yang berkelanjutan, seperti yang dikutip dalam Journal of Urban Society'S Arts: 
"Art works are not born just like that, but emerge from an idea which is then arranged conceptually. Artwork is expressed from a complex contextual and textual of the artworks making from thoughts and experiences that are sustainable". (Sri Rustiyanti, Wanda Listiani, Fani Dila Sari, IBG Surya Peradantha, 2019: 114).

Artinya, sebelum terbentuk ide, hal yang terlebih dahulu dilaksanakan adalah melakukan pengamatan terhadap tinggalan prasejarah situs Megalitik Tutari baik observasi langsung maupun kajian teks. Sebagai perbandingan, Eko Supendi dan Satriana Didiek Isnanta (2020; 38-41) dalam karyanya yang berjudul "Helai Kertas", sebuah karya koreografi site-specific, proses penciptaan karyanya tersebut meliputi tahapan sebagai berikut: (1). Eksplorasi Gagasan; (2). Kreasi Artistik, dan: (3). Pewujudan Karya. Dalam karya Tutari Megart Lithic ini, penulis melakukan proses yang hampir sama, antara lain: (1) riset; (2) Penentuan Gagasan; (3) Eksplorasi Bentuk; (4) Pewujudan, dan; (5) Pengayaan Artistik.

Dalam tahap pertama yaitu riset, dilakukan pengamatan mengenai jenis motif, makna, pengamatan geografis untuk menentukan lokasi penggarapan, wawancara terhadap narasumber dan pengamatan waktu untuk melihat faktor pencahayaan alam yang tepat di lokasi yang ditentukan. Tahap kedua yaitu penentuan gagasan, merupakan hasil dari proses riset berupa konsep garap yaitu menarikan motif. Berangkat dari konsep ini, lahirlah ide untuk menginterpretasikan motif-motif lukisan di atas batu ke dalam tubuh masing-masing penari dan membiarkan mereka berekspresi sesuai pengalaman estetis ketubuhan masing-masing. Berlanjut ke tahap ketiga yaitu eksplorasi bentuk, penulis membiarkan para penari untuk mencoba berbagai kemungkinan pola gerak, pose, desain tubuh dan motif-motif gerak yang merupakan re-interpretasi mereka terhadap motif lukisan yang dipilih. Penulis hanya memberikan motivasi terkait tampilan visual baik pose, pola, dan motif yang dibentuk oleh mahasiswa. Tahap keempat yaitu pewujudan adalah penggarpan struktur penampilan, penentuan konsep opening, isi, ending tandatanda penting dalam karya serta durasi pertunjukan. Terakhir, pada tahap kelima, penulis memberikan pengayaan artistik berupa penggarapan motif body painting yang diciptakan baru bersumber dari salah satu motif lukisan di Sektor 3 Situs Megalitik Tutari yang bernama motif Gelang Mas Kawin serta penggarapan musik iringan pertunjukan. Selain itu, pada bagian ini penulis juga memberikan finishing touch pada penggunaan ornamen kostum yang berasal dari vegetasi alami setempat.

\section{Pembahasan}

Penciptaan karya seni "Tutari MegArt Lithic" ini terwujud berkat beberapa sumber inpsirasi yang memicu gagasan kreatif mengapa tarian ini dapat terwujud, antara lain:

\section{A. Inspirasi Visual}

Menurut Tim Penyusun Buku Lukisan Megalitik Tutari (2018: 49), ada lima jenis lukisan yang berhasil dikelompokkan di Situs Megalitik Tutari, antara lain: a). Motif Manusia, b). Motif Flora, c). Motif Fauna, d). Motif Benda Budaya, dan e). Motif Geometris. Selain batu berlukis, ditemukan juga figur batu dan susunan batu berpola. Setelah dilakukan penelitian oleh Balai Arkeologi Papua, baik batu berlukis maupun figur dan susunan batu berpola ini ditemukan di 6 sektor, dimana sektor 1-3 berisi peninggalan batu berlukis berbagai motif, sektor 4 berisi peninggalan figur batu, sektor 5 berisi susunan batu berpola yang membentuk barisan serta sektor 6 yang berisi 110 buah menhir atau batu tegak yang berfungsi sebagai simbol pemujaan.

Dari berbagai model peninggalan kebudayaan batu di Situs Megalitik Tutari tersebut di atas, penulis tertarik akan motif- 
motif lukisan di atas batu yang tersebar di sektor 1-3. Keindahan visual motif yang terlukis di atas batu di sektor 1-3 memberikan daya tarik tersendiri yang tertuang tidak hanya melalui bentuk visualnya namun juga makna yang terkandung di dalamnya. Lukisan bermotif manusia, memiliki makna representasi roh nenek moyang yang dipercaya memiliki kekuatan perlindungan. Motif flora dan fauna memberikan informasi mengenai keterkaitan dan keseimbangan hidup manusia suku Tutari pada zaman dahulu terhadap peran tumbuhan dan hewan yang bermanfaat bagi kehidupan mereka. Motif geometris memberikan gambaran bahwa manusia pada masa lalu telah memiliki filosofi hidup yang dilambangkan melalui lukisan. Ada lukisan bermotif matahari yang menyimbolkan beberapa makna seperti menyembah dewa matahari sebagai pelindung, kepemimpinan dan lambang kehidupan. Motif lingkaran berjajar dengan garis di tengahnya/motif batu gelang melambangkan kebersamaan, jumlah ondofolo (pemimpin/kepala adat) secara turun temurun yang memimpin mereka, serta dapat bermakna sebagai lambang mas kawin yang hingga kini masih digunakan oleh masyarakat setempat saat upacara perkawinan.

Motif-motif ini memiliki kemungkinan yang luas untuk dieksplorasi sebagai sumber inspirasi penciptaan karya. Literasi bahasa tubuh penari merupakan pengalaman empirik yang dimiliki dalam kemampuan membaca koreografi dan melakukannya secara terus menerus sehingga koreografi yang dilakukan menjadi sebuah literasi bahasa tubuh yang terlatih menjadi corporal acrobatic, corporal impulses, corporal instinc, dan virtuisitas menjadi pengalaman estetis (Sri Rustiyanti, Wanda Listiani, Fani Dila Sari, Ida Bagus Gede Surya Peradantha, 2020: 453). Penulis kemudian memilih beberapa motif untuk dieksplorasi lebih lanjut yaitu motif soa-soa (kadal/biawak), motif kura-kura, motif ikan (Lihat pada Gambar 2 dan 3) serta motif gelang batu mas kawin (Lihat pada Gambar 4). Eksplorasi yang dilakukan antara lain eksplorasi gerak dan penghayatan karakter sesuai dengan motif lukisan yang dipilih dan didalami.

Tiga orang penari memilih masingmasing satu motif yang terlukis di atas batu, kemudian menginterpretasikannya sesuai pengalaman artistik dan ketubuhan masingmasing. Penulis membebaskan penari menginterpretasikan motif yang dipilih sembari sesekali memberikan masukan dan evaluasi. Eksplorasi rangsang visual ini bertujuan untuk menyatukan rasa antara tubuh penari dengan karakter motif yang

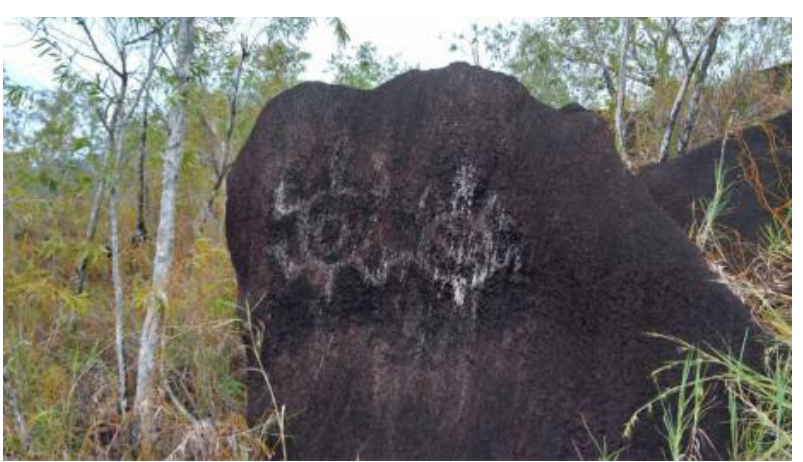

Gambar 2. Motif kura-kura di sektor 2 Situs Megalitik Tutari. Sumber: IBG. Surya Peradantha, 2019.

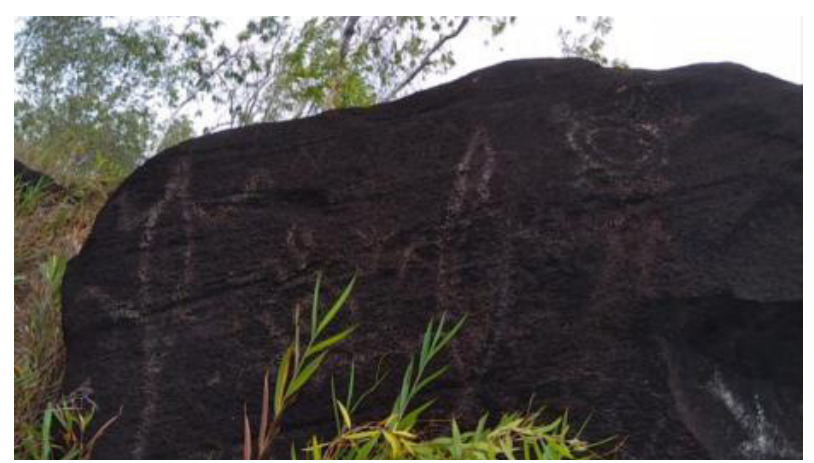

Gambar 3. Motif fauna berupa soa-soa dan kura-kura di sektor 2 Situs Megalitik Tutari. Sumber: IBG. Surya Peradantha, 2019.

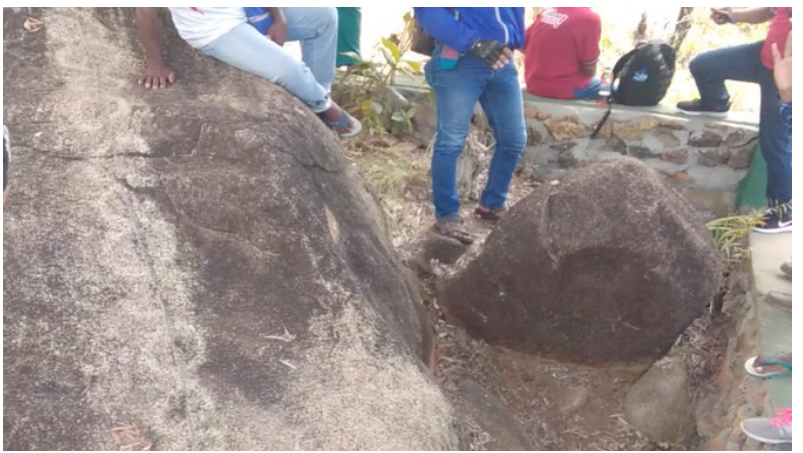

Gambar 4. Motif gelang batu mas kawin di sektor 3 Situs Megalitik Tutari. Sumber: IBG. Surya Peradantha, 2020. 
dipilih, serta memperoleh pengalaman artistik berupa pose-pose atau desain tubuh yang baru dan nyaman untuk dilakukan.

\section{B. Inspirasi Artistik}

Lokasi eksplorasi ditetapkan di Sektor 3 Situs Megalitik Tutari. Tempat ini dipilih karena beberapa hal. Pertama, sektor 3 ini adalah area yang paling aman secara kontur alam untuk melakukan eksplorasi gerak tari. Kedua, area ini relatif lebih sejuk karena dinaungi oleh pepohonan yang rindang sehingga memberikan nyaman saat eksplorasi dilakukan. Ketiga, ia memiliki penataan artistik yang alami. Hamparan batu besar berwarna hitam dan pepohonan kayu putih (Melaleuca leucadendra) yang batangnya terbakar secara alami memberikan kesan artistik yang sangat kuat dengan warna kontras hitam dari kulit pohon kayu putih yang terbakar alami serta dari batu-batu setempat serta warna putih dari batang pohon kayu putih yang alami. Keempat, area ini luas dengan beberapa batu berlukisan motif lukisan binatang yang tampak indah baik dilihat melalui mata maupun diamati dari kamera. Adapun sektor lain relatif kurang memberikan kemungkinan yang luas untuk melakukan eksplorasi gerak tari karena keadaan alaminya yang terjal serta luas area yang kurang proporsional.

Keadaan lokasi seperti itu memberikan kesempatan kepada penulis untuk melakukan olah gerak di tempat yang tidak memberikan hambatan. Penari menjadi lebih leluasa untuk melakukan eksplorasi dan improvisasi meski dengan gerakan-gerakan tubuh yang bersifat teknis seperti berdiri dengan menggunakan keseimbangan salah satu kaki serta akrobatakrobat tubuh lainnya.

Selain pengamatan mengenai motif lukisan sebagai sumber inspirasi gerak, motifmotif di atas batu tersebut juga dieksplorasi untuk untuk diaplikasikan sebagai motif body painting. Penggunaan body painting pada tari-tarian tradisional Papua pada umumnya biasa digunakan. Sebagaimana pengaplikasian motif di atas batu, motif- motif body painting pada tarian tradisional Papua juga menyimpan beragam pesan dan makna yang dapat memberikan kita informasi terkait kebudayaan dan pola hidupnya. Untuk itulah, dalam riset kekaryaan ini, dilakukan pengamatan motif-motif lukisan serta makna yang terkadung di dalamnya sebagai bahan artistik pengaplikasian body painting dalam karya tari.

Salah satu motif yang menurut penulis memberikan rangsang artistik paling kuat adalah motif gelang batu mas kawin yang dijumpai di Sektor 3. Secara filosofis, motif gelang batu mas kawin ini merupakan simbol budaya bagi masyarakat Suku Sentani di Bagian Barat (termasuk di Kampung Doyo Lama), bahwa mereka masih menggunakan gelang yang terbuat dari batu dan manik-manik sebagai mas kawin pernikahan (narasumber Hans Pangkatana, 18 Oktober 2020). Secara visual, motif ini cukup sederhana karena hanya terdiri dari dua pola yaitu lingkaran berjajar dan garis lurus di tengah-tengah. Makna yang bisa diinterpretasi dari motif ini adalah kebersamaan dan persatuan masyarakat sehingga menimbulkan kesan sederhana namun kuat. Motif ini kemudian menginspirasi penulis untuk menciptakan motif baru dalam body painting penari yang digunakan dalam karya "Tutari MegArt Lithic" (Lihat Gambar 5).

\section{Inspirasi Gagasan}

Inspirasi gagasan ini timbul dari proses wawancara bersama beberapa narasumber. Narasumber pertama adalah Hari Suroto

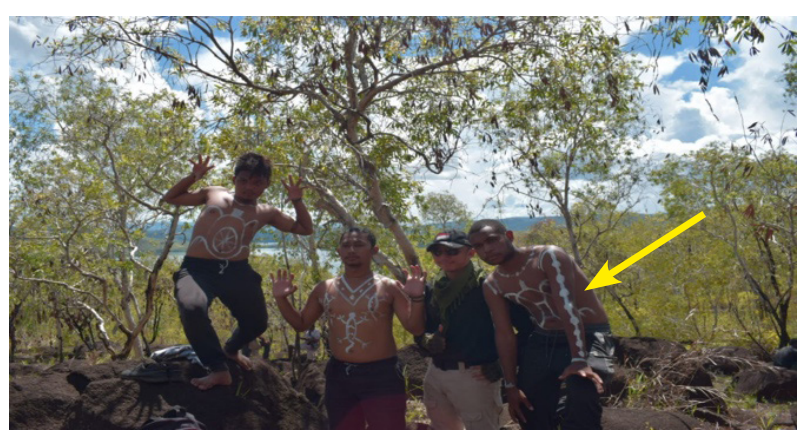

Gambar 5. Eksplorasi di Sektor 3 Situs Tutari bersama penari sekaligus mencoba aplikasi motif body painting baru pada bagian tangan penari. Sumber: IBG. Surya Peradantha, 25 Oktober 2020. 
dari Balai Arkeologi Papua yang memberikan penulis kesempatan bereksplorasi perdana di bulan November 2019. Dari Suroto, diperoleh informasi mengenai proses penelitian yang dilakukan oleh Balai Arkeologi Papua mengenai Situs Megalitik Tutari, pemetaan lokasi yang dibagi menjadi 6 sektor serta jenisjenis tinggalan yang ada di Situs Megalitik Tutari. Penulis juga berkesempatan berkeliling di semua sektor Situs Megalitik Tutari pada saat itu (lihat Gambar 6). Inspirasi menjadi timbul pada saat mengamati motif-motif lukisan di atas batu tersebut dengan ide menginterpretasi motif-motif tersebut ke dalam karya tari. Oleh karena keterbatasan waktu, pengamatan dilanjutkan pada kesempatan berikutnya.

Narasumber kedua adalah Hans Pangkatana (55) seorang tokoh masyarakat dari Suku Pangkatana yang mendiami wilayah Kampung Doyo Lama (lihat Gambar 7). Dari beliau diperoleh penjelasan mengenai gambaran kehidupan manusia Tutari masa lalu yang hidup dengan berburu dan meramu makanan di wilayah Bukit Tutari, serta kaitan antara motif lukisan batu dengan lingkungan sekitar dan kebudayaan manusia Tutari di masa lalu. Bukit Tutari terletak berhadapan langsung dengan Danau Sentani sehingga flora dan fauna danau memiliki kaitan erat dengan kehidupan masyarakat setempat bahkan hingga saat ini. Dari penjelasan beliau, secara umum dapat dilihat bahwa motifmotif khususnya flora dan fauna ini dilukis di atas batu oleh manusia Tutari masa lalu adalah sebagai kebiasaan bahwa setelah selesai berburu binatang, maka mereka akan melukiskan jenis binatang buruannya di atas batu. Selain itu, beberapa binatang seperti kura-kura dan soa-soa serta buaya juga dianggap sebagai representasi nenek moyang yang melindungi keberadaan seluruh anggota suku sehingga sangat dihormati. Untuk itulah, motif-motif kura-kura, soa-soa atau buaya dilukiskan di atas batu. Dari penuturan beliau pula, motif batu gelang ini masih digunakan sebagai mas kawin hingga kini oleh masyarakat kampung Doyo Lama, khususnya bagi angota kepala suku dan memiliki makna kekerabatan.

Hans Pangkatana juga memberikan informasi bahwa selain motif flora dan fauna, di situs Megalitik Tutari ini pula ada batu berlukis motif manusia. Figur dalam motif tersebut mencerminkan penghormatan terhadap leluhur laki-laki dan perempuan Suku Tutari. Dalam bahasa Sentani, leluhur

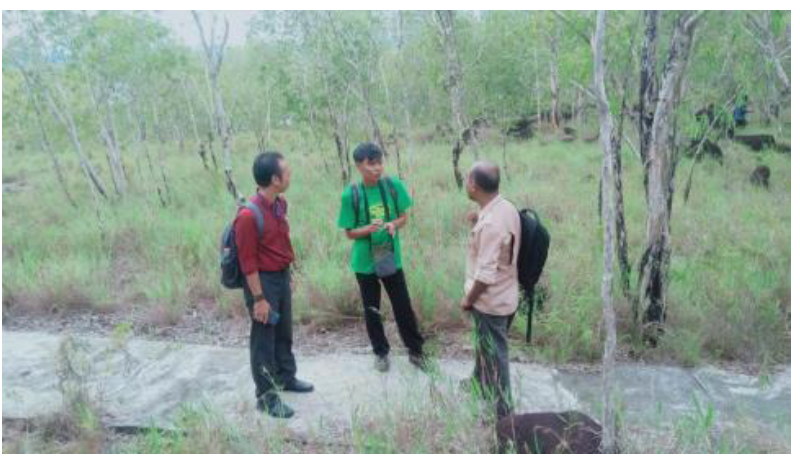

Gambar 6. Eksplorasi Situs Megalitik Tutari bersama Hari Suroto (tengah). Sumber: Yogi Rinaldo, November 2019.

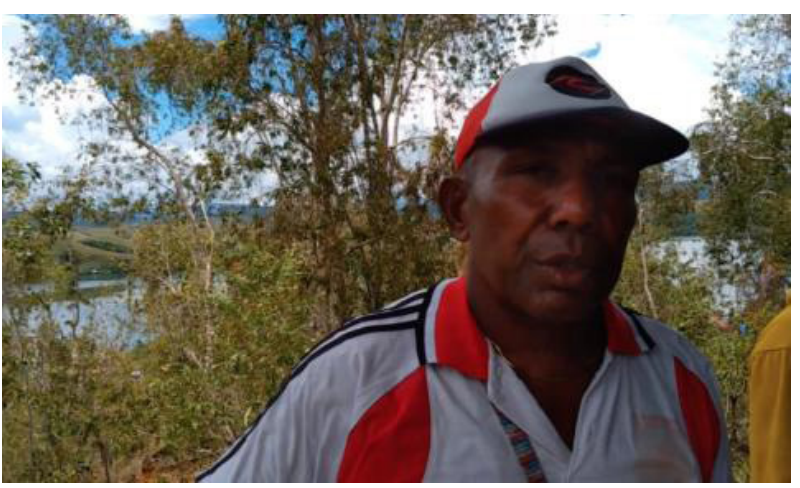

Gambar 7. Wawancara bersama Hans Pangkatana mengenai kaitan motif lukisan di Situs Megalitik Tutari dengan lingkungan sekitar dan kebudayaan Suku Tutari di masa lampau. Sumber: IBG. Surya Peradantha, 2020.

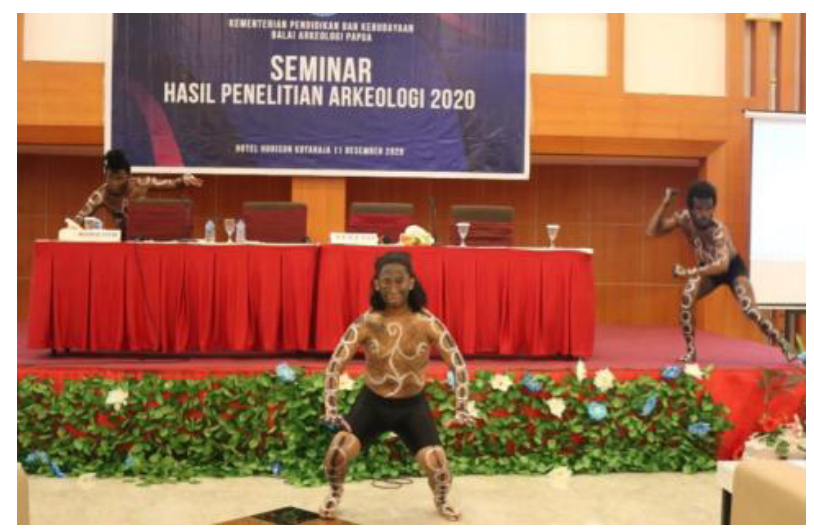

Gambar 8. Tari "Tutari MegArt Lithic" karya IBG. Surya Peradantha dipentaskan di panggung. Sumber: Balai Arkeologi Papua, 2020. 
laki-laki disebut dengan istilah do dan leluhur perempuan disebut dengan istilah me. Selain unsur vokal, penciptaan musik karya juga memanfaatkan alat-alat dari alam sekitar berupa serpihan batu dan kayu, Melalui konsep musik ini, penulis berniat mengucapkan rasa terima kasih kepada para leluhur Suku Tutari baik laki-laki maupun perempuan yang telah mewariskan peninggalan budaya yang adiluhung ini.

Dari keterangan wawancara kedua narasumber tersebut di atas, penulis memperoleh rangsang gagasan mengenai konsep kekaryaan yang digarap. Adapun konsep "lukisan menari" yang dimaksud adalah reinterpretasi motif lukisan ke dalam karya tari, dimana penari memiliki kebebasan untuk menginterpretasi motif lukisan yang diamati untuk kemudian mewujudkannya ke dalam desain-desain gerak baru yang dihasilkan dari proses eksplorasi dan improvisasi personal.

KaryatariTutari MegArtLithicinimemiliki keberlanjutan dengan dipentaskannya kembali tarian ini di Hotel Horison, Kotaraja pada 11 Desember 2020 (lihat pada Gambar 8). Sebagaimana salah satu karakteristik karya koreografi site specific yang tidak dapat dipentaskan di tempat selain karya itu diciptakan, maka karya ini harus mengalami penyesuaian kembali secara koreografi karena dipentaskan dalam format pemanggungan. Unsur-unsur lain seperti motif body painting dan musik tidak mengalami perubahan karena telah memiliki kebakuan hasil dari riset yang dilakukan sebelumnya di Situs Tutari.

\section{Penutup}

Karya Tari Tutari MegArt Lithic ini adalah salah satu karya kreasi baru dengan pendekatan garap koreografi site-specific di Situs Megalitik Tutari. Penciptaan karya ini terinspirasi dari beberapa menarik yang lahir dari kajian mengenai tinggalan situs baik secara visual, artistik maupun gagasan. Secara visual, tinggalan berupa motif lukisan di Situs Megalitik Tutari sangat menginspirasi dan memberikan rangsang kreatif bagi penulis. Keunikan bentuk dan warna motif di atas batu tersebut sangat memungkinkan untuk direspons secara ketubuhan untuk membentuk suatu desain gerak yang di luar kebiasaan penari di atas panggung. Secara artistik, kembali motif-motif lukisan di atas batu Situs Megalitik Tutari memberi rangsang kreatif bagi penciptaan motif-mptif body painting yang digunakan pada tubuh para penari yang sama sekali baru tanpa mengembangkan motif-motif body painting tradisional yang telah ada sebelumnya. Secara gagasan, hasil riset melalui wawancara dengan tokoh masyarakat setempat memberikan informasi lebih mendalam mengapa para manusia penghuni situs Tutari pada masa lalu menggambar berbagai motif di atas batu dan apa maknanya, memberikan rangsang kreatif bagi penulis untuk mewujudkan gagasan kekaryaan.

Penciptaan karya koreografi lintas disiplin ilmu ini dapat memberikan wacana baru bagi pengembangan penciptaan karya seni selanjutnya di Tanah Papua. Tak hanya Situs Megalitik Tutari, ada banyak situs serupa yang masih belum tergali lebih dalam potensinya, khususnya dari perspektif penciptaan karya koreografi. Selain untuk menyegarkan warna karya tarian kreasi baru yang diciptakan, koreografi site-specific dapat memberikan tambahan wawasan berkat hal-hal penting yang terkandung dalam suatu tempat yang perlu digali dan diinterpretasi.

\section{Ucapan Terima Kasih}

Ucapan terima kasih kepada Ristek-BRIN yang telah memberi dana Hibah Penelitian Penugasan Konsorsium Riset Perguruan Tinggi Bidang Seni Pertunjukan tahun 2019-2021 dan PT. Assembrl Teknologi Indonesia sebagai Mitra Penelitian serta Perguruan Tinggi Seni anggota Konsorsium Seni yaitu Institut Seni Budaya Indonseia (ISBI) Bandung, Institut Seni Budaya Indonseia (ISBI) Aceh dan Institut Seni Budaya Indonseia (ISBI) Tanah Papua. 


\section{Kepustakaan}

Edensor, Tim. 2015. Site-Specific Dance: Revealing and Contesting The Ludic Qualities, Everyday Rhythms, And Embodied Habits Of Place. Environment and Planning A 2015, volume 47, 709 726.

Hunter, Victoria. 2005. Embodying the Site: the Here and Nowin Site-Specific Dance Performance. New Theater Quarterly Journal, Vol.21, Issue 4. London: Cambridge University Press.

Kloetzel, Melanie and Carolyn Pavlik. 2009. Site Dance. Florida, USA: The University of Florida Press.

Novita Idje Djami, Erlin dan Hari Suroto. 2017. Makna Motif Lukisan Megalitik Tutari. Jurnal Papua, Vol. 9 No. 1, Juni 2017, 4957.

Nurulakmal binti Abdul Wahid, Mumtaz Begoo Aboo Becker dan Muhizam Mustafa. 2020. Ruang dan Memori dalam Koreografi SiteSpecific: Kajian Terhadap Karya City of Entertainment Oleh Lee Ren Xin. Jurnal Gendang Alam, Jilid 10 (2), 2020.

Shinta Kusuma, Hirwan Kuardhani, dan Rukman Rosadi. 2020. Penciptaan Peran Tokoh Xiau Mei dalam Naskah Senja dan Penantian Karya Hernandes Saranela Terinspirasi dari Film The Chinese Widow. Dance and Theatre Review Vol. 3 No. 2, November 2020, 82 - 95.

Sri Rustiyanti. 2019. Metode 'TaTuPa' Tabuh Tubuh Padusi sebagai Musik Internal Visualisasi Koreografi NeoRandai. Jurnal Resital Vol 20. No.3 Desember 2019, 161-
175.

Sri Rustiyanti, Wanda Listiani, Fani Dila Sari, Ida Bagus Gede Surya Peradantha. 2019. Aesthetic Transformation in the Production Process of the Augmented Reality Folklore Pasua Realtime Performance. Journal of Urban Society's Vol 6. No.2 Oktober 2019, 112-122.

Sri Rustiyanti, Wanda Listiani, Fani Dila Sari, Ida Bagus Gede Surya Peradantha. 2019. Literasi Tubuh Virtual dalam Aplikasi Teknologi Augmented Reality Pasua PA. Jurnal Panggung Vol 30. No. 3 Oktober 2020, 453-464.

Supendi, Eko dan Satriana Didiek Isnanta. 2020. Studi Penciptaan Karya Site Specific Dance Helai Kertas. Jurnal Acintya Vol.12 No. 1, Juni 2020.

Sunarto, B. 2013. Epistemologi Penciptaan Seni. Yogyakarta: Idea Press.

Suroto, Hari, Erlin N. I. Djami, M. Irfan Mahmud. 2011. Ekskavasi dan Survei Arkeologi di Kawasan Danau Sentani. Balai Arkeologi Papua.

Suvina, Martion Martion, Ali Sukri. 2020. Garapan Tari "Akegh Cahayegh": Representasi Budaya Ritual Pengobatan Tolak Bala Suku Talang Mamak, Desa Gedabu. Jurnal Dance and Theatre Review Vol. 3 No. 2, November 2020, page 96-103.

Tim Penyusun. 2018. Mulok Kebudayaan Papua: Situs Megalitik Tutari. Jayapura: Badan Penerbitan Balai Arkeologi Papua. Zaim, Yahdi dan Haroen. 1979. Geologi Tinjau Sepanjang Jalan Genyem-Sentani Jayapura dan Pulau-Pulau di Danau Sentani. Pusat Penelitian Arkeologi Nasional. 